\title{
DIRECTORS' AND OFFICERS' LIABILITY INSURANCE
}

\author{
KENNETH B. POTTER*
}

A relatively new concept in corporate affairs, that of liability insurance for directors and officers of companies, is examined in its Canadian and particularly in its Albertan context. This examination is conducted against the background of possible liabilities of directors at common law and under sta. tute, and the ability of companies to indemnify their directors for such liabilities. The clauses of and coverage provided by a typical directors' and officers' liability policy are analyzed and the merits of such a policy discussed in the context of its possible worth to a corporation. This analysis will be of particular worth and interest to corporate lawyers employed in an advisory capacity by corporations.

The subject of directors' and officers' liability insurance has been receiving a considerable amount of attention in law offices across Canada in the past year or two. To a large extent this concern was the result of the amendments proposed to the Ontario Corporations Act by the Select Committee on Company Law and of The Business Corporations Act, 1968, ${ }^{1}$ which was introduced into the Ontario Legislature by Premier Robarts and which was intended primarily as a centre for discussion on Company Law reforms. ${ }^{2}$ This Act proposed many amendments to old statute law and the common law and some amendments had the result of increasing the potential liability of corporate directors. It is the object of this paper to review briefly the liability of directors and officers and to then review the more or less standard form of directors' and officers' liability insurance policy in order that conclusions may be drawn as to the value of such insurance.

While it is not the intention of this paper to be a treatise on the liability of directors, it is essential to an evaluation of this type of insurance that one be briefly familiar with the liability of a director. The liability of a director or officer stems from two sources-the common law and statute law.

\section{COMMON LAW LIABILITY OF DIRECTOR}

The common law liability of a director can be conveniently discussed under two headings-fiduciary duties and duties of skill and care. ${ }^{3}$

A director is in a fiduciary relationship to the company and must act bona fide in good faith toward the company in dealing both with it and on its behalf. In testing whether a director has acted bona fide, the court in the words of Lord Green in Re Smith \& Fawcett Ltd. ${ }^{4}$ attempts to see that "they must exercise their discretion bona fide in what they consider-not what the court may consider-to be in the interests of the company, and not for any collateral purpose". Gower ${ }^{5}$ states that compliance with this rule is tested on common sense principles and that the court should ask itself first whether the

\footnotetext{
- B.A., LL.B. (Alta.) of the firm of Macleod, Dixon, Calgary, Alberta.

I Bill 125 introduced into the First Session of the 28th Legislature of Ontario on May 17, 1968. This Bill was never proceeded with.

2 See Legislative Assembly of Ontario Debates, Friday, May 17, 1968.

3 These headings provide a convenient division for purposes of discussion but are actually less distinct than such a treatment would indicate.

4 [1942] 1 All E.R. 542 at 543.

3 Gower, The Principles of Modern Company Law (3rd ed. 1969) at 520.
} 
directors have done what they honestly believe to be right, and normally accepting that they have, then whether they have behaved as honest men in business might be expected to behave. He summarizes the fiduciary obligations as follows: ${ }^{6}$

The general principles in their application have four facets which are probably best treated as distinct, though in practice they tend to overlap. First, the directors must act bona fide, that is, in what they believe to be the best interests of the company. Secondly, they must exercise their powers for the particular purpose for which they were conferred and not for some extraneous purpose, even though they honestly believe that to be in the best interest of the company. Thirdly, they must not fetter their discretion to exercise their powers from time to time in accordance with the foregoing rules. And finally, despite compliance with the foregoing rules, they must not, without the consent of the company, place themselves in a position in which there is a conflict between their duties and their personal interests.

Their fiduciary obligations prevent them from making secret profits through such acts as accepting bribes, and appropriating corporate advantages to themselves. The fiduciary duties are owed to the company and not to the individual shareholders. ${ }^{7}$ The fiduciary duties are analogous to those of a trustee and a high standard of conduct is required.

A director may also be personally liable for application of the company's assets on ultra vires transactions. ${ }^{8}$ This liability is to make restitution to the company for the misappropriated assets. There is also some authority for the proposition that the liability may also extend to the third parties with whom they were dealing. ${ }^{9}$

A director is also liable for his negligent acts done towards the company. Directors owe a duty of reasonable care and skill to the company but the standard is not a very stringent one. One of the earliest formulations of a director's liability for negligence occurred in the case of The Charitable Corporation v. Sutton where Lord Hardwick said:10

(Directors) may be guilty of acts of commission or omission, of mal-feasance or non-feasance... By accepting a trust of this sort, a person is obliged to execute it with fidelity and reasonable diligence; and it is no excuse to say that they had no benefit from it, but that it was merely honorary; and therefore, they are within the case of common trustees.

This case can be considered as something of a high-water mark in the standard of care that the law has demanded of directors. It imposes obligations similar to those of a trustee but the courts have, apart from the fiduciary concepts, since abandoned the concept of trusteeship as applied to directors."11

One of the lowest standards of care was stipulated in the case of Turquand v. Marshall where it was stated:12

It was within the powers of the deed to lend to a brother director, and however foolish the loan might have been, so long as it was within the power of the directors, the Court could not interfere and make them liable... Whatever may have been the amount lent to anybody, however ridiculous and absurd this conduct might seem, it was the misfortune of the company that they chose such unwise directors;

\footnotetext{
- Supra, n. 5.

7 Percival v. Wright [1902] 2 Ch. 42.

- Re Faure Electric Accumulator Co. (1888) 40 Ch. D. 141; Cullerne v. London \& Suburban Building Society (1890) 25 Q.B.D. 485

Sinclair v. Brougham [1914] A.C. 398; Re Diplock [1948] Ch. 465 and Gower, supra, n. 5 at 94-95.

${ }^{10}$ (1742) 2 Atk. 400 at 405, 26 E.R. 642 at 644.

1" Re City Equitable Fire Insurance Company [1925] Ch. 407 at 426.

12 (1869) L.R. 4 Ch. App. 376 at 386.
} 
but as long as they kept within the powers of their deed, the Court could not interfere with the discretion exercised by them.

While the exact nature of the director's duties and standard of care are unclear it is submitted that at present the standard lies somewhere between these two extremes.

One of the most authoritative statements and the one expressing the law as it most likely is today is the case of Re City Equitable Fire Insurance Company where Romer, J. stated: ${ }^{13}$

In order, therefore, to ascertain the duties that a person appointed to the board of an established company undertakes to perform, it is necessary to consider not only the nature of the company's business, but also the manner in which the work of the company is in fact distributed between the directors and the other officials of the company, provided always that this distribution is a reasonable one in the circumstances, and is not inconsistent with any express provisions of the articles of association. In discharging the duties of his position... a director must, of course, act honestly; but he must also exercise some degree of both skill and diligence. To the question of what is the particular degree of skill and diligence required of him, the authorities do not, I think, give any clear answer. It has been laid down that so long as a director acts honestly he cannot be made responsible in damages unless guilty of gross or culpable negligence in a business sense. ... If, therefore, a director is only liable for gross or culpable negligence, this means that he does not owe a duty to his company, to take all possible care. It is some degree of care less than that.

There are in addition one or two other general propositions that seem to be warranted by the reported cases: (1) A director need not exhibit in the performance of his duties a greater degree of skill than may reasonably be expected from a person of his knowledge and experience... In the words of Lindley, M.R.: "If directors act within their powers, if they act with such care as is reasonably to be expected from them, having regard to their knowledge and experience, and if they act honestly for the benefit of the company they represent, they discharge both their equitable as well as their legal duty to the company."... It is perhaps only another way of stating the same proposition to say that directors are not liable for mere errors of judgment. (2) A director is not bound to give continuous attention to the affairs of his company. His duties are of an intermittent nature to be performed at periodical board meetings, and at meetings of any committee of the board upon which he happens to be placed. He is not, however, bound to attend all such meetings, though he ought to attend whenever, in the circumstances he is reasonably able to do so. (3) In respect of all duties that having regard to the exigencies of business and the articles of association, may properly be left to some other official, a director is, in the absence of grounds for suspicion, justified in trusting that official to perform such duties honestly.

This case, which can be considered as representing the present duty of care, obviously postulates low standards and at any rate standards much lower than those of a trustee. One reason for this lower standard is that directors must take chances in the course of directing the company whereas this is not the function of trustees. Also many directors do not devote their full time to the affairs of the company and just accept the position as a sinecure and the courts are unwilling to impose harsh obligations on a part time endeavour.

Directors are also very often shareholders of the company that they are directors of, and in such a situation it is necessary to reconcile the directors' fiduciary obligations to all the company with their obviously private interests. The courts have taken a reasonable view of the dilemma. In the Australian case of Mills v. Mills, Latham, C.J. stated: ${ }^{14}$

A director who holds one or both classes of shares is not, in my opinion, required

is [1925] Ch. 407 at $427-29$.

14 [1937]60 C.L.R. 150 at 164. 
by the law to live in an unreal region of detached altruism and to act in a vague mood of ideal abstraction from obvious facts which must be present to the mind of an honest and intelligent man when he exercises his powers as a director. It would be setting up an impossible standard to hold that, if an action of the director were effected in any degree by the fact that he was a preference or ordinary shareholder, his action was invalid and should be set aside.

A director also faces a potential common law liability to a shareholder in the tort of deceit for misstatements in a prospectus. A leading case in this field is Derry v. Peek ${ }^{15}$ which established that in order to succeed a shareholder must prove a misrepresentation was made fraudulently, which in this context means that the false representation was made knowingly, or without belief in its truth, or recklessly not caring whether it is true or false. There need be no malicious intent on the part of the director. A director is exonerated from liability under this tort if he made the statement believing it to be true even though he had no reasonable grounds for this belief. ${ }^{16}$ The test is a subjective one. ${ }^{17}$ Normally an omission to state a material fact will not suffice but if the omission causes the prospectus as a whole to give a misleading impression or falsifies one of the statements in it, this will give rise to a cause of action. ${ }^{18}$ In order to succeed the shareholder must be able to show that he is one of a class of persons intended to act on it. ${ }^{19}$ Thus, in Peek v. Gurney ${ }^{20}$ it was held that a purchaser who purchased on the market on the faith of a prospectus published on the issue of the shares could not recover as the prospectus was intended only to induce subscriptions from the Company, and not purchases on the market. If it can be shown that the prospectus was intended to induce market dealings then liability can follow. ${ }^{21}$ This cause of action is fairly difficult to establish and inasmuch as a purchaser has a better remedy under the Companies Act ${ }^{22}$ and Securities Act ${ }^{23}$ of Alberta it is doubtful that many actions on the basis of deceit will be brought.

The indexes and digests of Canadian law are not replete with cases on the subject of directors' liability because such actions are rarely brought. This lack of cases is due at least in part to what has become known as the rule in Foss v. Harbottle. ${ }^{24}$ The rule stands for the general proposition that a shareholder may not maintain an action to remedy an alleged wrong to the company as the corporation is the only person who may sue in respect of such wrong. This rule has no application where the rights of individual shareholders are infringed but only applies where the rights invaded are the rights of the company. ${ }^{25}$ The rule and its exceptions have been summarized by Jenkins, L.J. in Edwards v. Halliwell as follows: ${ }^{26}$

is (1889) 14 A.C. 337. See also Nesbitt, Thomson \& Co. v. Pigott [1941] S.C.R. 520.

is Derry v. Peek (1889) 14 A.C. 337; Ankerhielm v. De Mare [1959] A.C. 789.

17 Ankerhielm v. De Mare, supra, n. 16 at 805.

in Peek v. Gurney (1873) L.R. 6 H.L. 377; Aaron's Reefs, Led. v. Twiss [1896] A.C. 273.

19 Peek v. Gurney (1873) L.R. 6 H.L. 377.

${ }^{20}$ Id.

21 Andrews v. Mockford [1896] 1Q.B. 372.

22 R.S.A. 1970, c. 60, s. 96.

${ }^{23}$ R.S.A. 1970 , c. 333 , s. 141.

24 (1843) 2 Hare 461, 67 E.R. 189. For excellent discussions of this rule see Ziegel, Canadian Company Law at 545; Beck, An.Analysis of Foss v. Harbottle, and MacIntosh, Shareholders' Actions, (1968) LS.U.C. Special Lectures 159.

${ }^{25}$ Edwards v. Halliwell $[1950\} 2$ All E.R. 1064.

2h Id., at 1066. 
The rule in Foss v. Harbottle, as I understand it, comes to no more than this. First the proper plaintiff in an action in respect of a wrong alleged to be done to a company or association of persons is prima facie the company or association of persons itself. Secondly, where the alleged wrong is a transaction which might be made binding on a company or association and on all its members by a simple majority of the members, no individual member of the company is allowed to maintain an action in respect of that matter for the simple reason that, if a mere majority of the members of the company or association is in favour of what has been done, then cadit quaestio. No wrong has been done to the company or association and there is nothing in respect of which any one can sue. If, on the other hand, a simple majority of members of the company or association is against what has been done then there is no valid reason why the company or association itself should not sue. In my judgment, it is implicit in the rule that the matter relied on as constituting the cause of action should be a cause of action properly belonging to the general body of corporators or members of the company or association as opposed to a cause of action which some individual member can assert in his own right.

The cases falling within the general ambit of the rule are subject to certain exceptions. It has been noted in the course of argument that in cases where the act complained of is wholly ultra vires the company or association the rule has no application because there is no question of the transaction being confirmed by any majority. It has been further pointed out that where what has been done amounts to what is generally called in these cases a fraud on the minority and the wrongdoers are themselves in control of the company, the rule is relaxed in favour of the aggrieved minority who are allowed to bring what is known as a minority shareholders' action on behalf of themselves and all others. The reason for this is that, if they were denied that right, their grievance could never reach the court because the wrongdoers themsleves, being in control, would not allow the company to sue... There is a further exception which seems to me to touch this case directly. That is the exception noted by Romer, J. in Cotter v. National Union of Seamen. He pointed out that the rule did not prevent an individual member from suing if the matter in respect of which he was suing was one which could validly be done or sanctioned, not by a simple majority of the members of the company or association, but only by some special majority, as, for instance, in the case of a limited company under the Companies Act, a special resolution duly passed as such. As Romer, J., pointed out, the reason for that exception is clear, because otherwise, if the rule were applied in its full rigour, a company which, by its directors, had broken its own regulations by doing something without a special resolution which could only be done validly by a special resolution could assert that it alone was the proper plaintiff in any consequent action and the effect would be to allow a company acting in breach of its articles to do de facto by ordinary resolution that which according to its own regulations could only be done by special resolution.

Therefore, a shareholder who feels he has been wronged or who is not satisfied with the conduct of the company's affairs faces certain procedural obstacles which are often insurmountable.

If a director is found to be negligent or in breach of trust he may rely on Section 273 of the Alberta Companies Act ${ }^{27}$ which provides that if in any proceeding against a director for negligence or breach of trust it appears to the Court that a director is or may be liable in respect of negligence or breach of trust, but has acted honestly and reasonably and ought fairly to be excused for the negligence or breach of trust, the Court may relieve him wholly or partly from his liability on such terms as the Court thinks proper. This Section of the Alberta Act has never been judicially considered. However, the comparable section in the English Companies Act has been judicially considered and the Courts have exhibited a reluctance to relieve a director on the basis of this section once he is shown to be otherwise 
liable. ${ }^{28}$ However, the Court in the case of Re Gilt Edge Safety Glass, Limited $^{29}$ held that directors who had inadvertently continued to act as directors after they had, owing to a reduction of capital, ceased to hold qualifying shares of the minimum value required by the Articles of Association ought to be excused on the basis of this section. In the case of National Trustees Company of Australia, Limited v. General Finance Company of Australasia, Limited, ${ }^{30}$ the Court in considering an analogous section of the Victorian Trusts Act, $1901,{ }^{31}$ of Victoria held that the fact that administering trusts was the trustees' business, and the fact that he was being paid, made it unlikely that the trustee ought fairly to be excused even though they acted honestly and reasonably. On the basis of English jurisprudence it would seem that this section would not be of much help to a director who is otherwise liable and a director would be ill advised to depend on this Section as his only means of protection.

\section{STATUTORY LIABILITY}

The Alberta Companies Act ${ }^{32}$ and the Alberta Securities Act ${ }^{33}$ have extended the common law liability of a director and imposed obligations and liabilities upon directors in certain specific circumstances. For example, the Companies Act, ${ }^{34}$ Section 85 , imposes liability on a director for employees' wages, Section 14 (3) imposes liability for loans to directors or officers or shareholders of public companies, Section 89 (3) provides that if dividends are paid when the company is insolvent or which render the company insolvent or the dividend when paid impairs capital, the directors are jointly and severally liable to the company and creditors for the debts then existing or thereafter contracted. By Section 96 of the Companies Act ${ }^{35}$ and Section 141 of the Securities Act, ${ }^{36}$ directors named in a prospectus are liable to pay compensation to all persons who subscribed for shares or apply for membership on the faith of it, for loss sustained by reason of the untrue statements therein. In certain circumstances they are relieved from liability. ${ }^{37}$ These obligations and liabilities could be the source of severe financial loss to a director. The New York case of Escott v. Barchris Construction Corporation ${ }^{38}$ which interpreted the comparable provisions of the Securities Act of $1933^{39}$ demonstrates that it is not hard for a director to make errors such that he becomes liable under this type of legislation.

Section 88e of the Companies Act ${ }^{40}$ and Section 113 of the Secur-

24 See Re J. Franklin and Son Ltd. [1937] 4 All E.R. 43; In re Duomatic Ltd. [1969] 2 W.L.R. 114; Selangor United Rubber Estates Ltd. v. Cradock [1968] 1 W.L.R. 1555 at 1659. This Section was successfully invoked by a director in Re Claridge's Patent Asphalte Company, Limited [1921] I Ch. 543 where the director, acting on Counsel's opinion entered into an ultra vires transaction.

29 [1940] Ch. 495.

30 [1905] A.C. 373.

31 Victorian Trusts Act, 1901, s. 3.

32 R.S.A. 1970, c. 60.

33 R.S.A. 1970, c. 333.

34 R.S.A. 1970, c. 60.

${ }^{35}$ R.S.A. 1970, c. 60.

${ }^{36}$ R.S.A. 1970, c. 333.

${ }^{37}$ See Companies Act, R.S.A. 1970, c. 60, s. 96 (2) and Securities Act, R.S.A. 1970, c. 333, s. 141.

38 (1968) 283 F. Supp. 643, and for a very good discussion of this case see Black and Britton, Recent Developments Under Securities Regulations in the United Staes, (1970) 8 Alta. L Rev. 432.

39 Public-No. 22-73D Congress.

เ0 R.S.A. 1970 , c. 60. 
ities Act ${ }^{41}$ impose liability on an insider (which includes directors) who in connection with transactions relating to the capital securities of the corporation makes use of specific confidential information for his own benefit, that, if generally known, might reasonably be expected to materially affect the value of the securities. The liability is to compensate any person for direct loss suffered as a result of such transaction, unless such person ought to have known the information, and the insider must further account to the corporation for any benefit received.

\section{RECENT STATUTORY TRENDS}

The recent enactment in Ontario of the Business Corporations Act, 1970,42 may be viewed as the beginning of a trend towards higher degrees of care being demanded of directors. When the Honorable John Robarts, Premier of Ontario, introduced the Business Corporations Act, 1968, to the Ontario Legislature he stated:43

...the new legislation imposes a high standard of accountability for the actions and inactions of all persons who assume positions of authority in a corporation, whether as directors, officers, auditors, or trustees under corporate trust indentures. This accountability is to the shareholders of the corporation, to its creditors and to the public, either directly or through the courts.

As has been earlier stated under the Rule in Foss v. Harbottle ${ }^{44}$ it is difficult for a shareholder to bring an action against the directors for a wrong suffered by the company. This difficulty has been dealt with in the Business Corporations Act, $1970^{45}$ by Section 87 which provides that a shareholder may with leave of the court maintain an action in a representative capacity for himself and all other shareholders of the corporation suing for and on behalf of the corporation to enforce any right, duty or obligation owed to the corporation under any act or rule of law that could be enforced by the corporation itself or to obtain damages for any breach of any such right, duty or obligation.

The Ontario Act ${ }^{46}$ by Section 144 provides a statutory standard of care which provides that:

Every director and officer of a corporation shall exercise the powers and discharge the duties of this office honestly, in good faith and in the best interests of the corporation, and in connection therewith shall exercise the degree of care, diligence and skill that a reasonably prudent person would exercise in comparable circumstances.

The first portion of this section creates a statutory fiduciary duty. It is doubtful if this is meant to entirely displace the common law fiduciary duty as at common law more than good faith and honesty is required. For example, cases have held that a director who makes a profit which he would not have made if he had not been a director is accountable to the company, notwithstanding that he acted in good faith and honestly. ${ }^{47}$ The latter portion of the section enacts a standard of care to be observed by directors. The words "in similar circumstances" allow a court to take into account the many variables

\footnotetext{
1 R.S.A. 1970, c. 333.

42 S. Ont. 1970, c. 25 (Interim Edition).

${ }^{43}$ Legislative Assembly of Ontario Debates, Friday, May 17, 1968. This Act was the forerunner of the Business Corporations Act, 1970.

“4 (1843) 2 Hare 461, 67 E.R. 189.

45 S. O. 1970, c. 25 (Interim Edition).

${ }^{46}$ Id.

47 See Regal (Hastings), Ltd. v. Gulliver [1942] 1 All E.R. 378.
} 
such as the amount of time available for making the decision in question which the director had to consider in making his decisions. ${ }^{48}$ There is a question as to whether completely subjective factors may be considered.

The Act $^{49}$ also provides that a director or officer cannot be indemnified by the corporation in respect of any costs, charges or expenses that he sustains or incurs in any action or proceeding as a result of which he is adjudged to be in breach of any duty or responsibility imposed upon him under any Act or rule of law or equity unless he has achieved complete or substantial success as a defendant. This is a substantial departure from the common law position. ${ }^{50}$

Section 147 (3) of the Act ${ }^{51}$ expressly authorizes a company to buy insurance for the director's benefit except as regards insurance against liability for costs, charges or expenses incurred as a result of the director failing to live up to the legislated standard of care.

The trend towards increased care being demanded of directors and officers was even more recently carried further by the passage of Bill C-452 -being an Act to Amend the Canada Corporations Act. This Act imposes fines ${ }^{53}$ and/or jail terms on directors or officers for such things as breach of the new insider trading provisions, ${ }^{54}$ breach of the new proxy provisions, 55 failure to file returns, reports, records, bylaws, statements or other documents after request by the Minister, ${ }^{56}$ failure to provide and file copies of the required financial statements, ${ }^{57}$ failure to file annual returns, ${ }^{58}$ and breach of the new takeover bid provisions. ${ }^{59}$

In addition to these fines it would appear that the Minister of Consumer and Corporate Affairs can bring actions against insiders who make a profit by reason of the use of confidential information ${ }^{60}$ and under the investigation sections the Minister can also bring actions based on the investigator's report for inter alia acts performed in a manner prejudicial to the interests of the shareholders. ${ }^{61}$

\section{ABILITY OF A COMPANY TO INDEMNIFY}

Many standard forms of Articles of Association presently in use in Alberta contain provisions to the effect that directors shall receive indemnification from all costs, losses and expenses which any such director shall incur or become liable to by reason of any contract entered into or act or thing done by him as director, and further that

\footnotetext{
4" In Re City Equitable Fire Insurance Company [1925] Ch. 407 the Court looked at the distribution of work between directors and the nature of the business 80 this is not a radical departure from the common law.

9 S.O. 1970, c. 25, 8. 147(2) (Interim Edition).

so At common law a company can indemnify negligent directors - Re Brazilian Rubber Plantations and Estates, Ltd. [1911] 1 Ch. 425 and Re City Equitable Fire Insurance Company [1925] Ch. 407.

3t S. O. 1970, c. 25 (Interim Edition).

32 An Act to Amend the Canada Corporations Act, S.C. 1969-70, c. 70.

st The amounts of these fines vary-some are on a per diem basis and some are set so as not to exceed $\$ 1,000.00$.

st Id., sections 98 to $98 \mathrm{~F}$.

ss Id., sections $106 \mathrm{~A}$ to $106 \mathrm{H}$.

st Id., section 112B.

3) Id., section 121E.

S* Id., section 125 .

Id., sections 127A to $127 \mathrm{~L}$

(1) Id., section 98D.

"I Id., section 112. This would seem to be wide enough to include negligence.
} 
he shall be indemnified by the company against the reasonable expenses, including attorney's fees incurred by him in connection with defending an action against him commenced by reason of the fact that he is a director, except in relation to matters as to which he is liable for negligence or misconduct in the performance of his duties. According to the present jurisprudence it would appear that such a clause is valid and further, that clauses purporting to cover liability for negligence itself are valid. 62

Some jurisdictions ${ }^{63}$ have provisions in their Companies Acts which provide that any provision in the articles or a contract which exempts an officer from liability which by virtue of any rule of law would otherwise attach to him is void.

There are arguments based on public policy that a company should not be able to indemnify a director against liability for certain types of conduct. ${ }^{64}$ These arguments are based upon the premise that to allow compensation in these cases is to encourage recklessness and negligent conduct and that to allow indemnification would be to remove completely the liability for negligence which the common law has established should attach in certain rare circumstances. There would seem to be no reason to oppose indemnification where the acts in question are unintentional wrongs or normal unthinking negligence. However, there are valid public policy arguments to be made against a company reimbursing its directors for responsibility to reimburse those whom they injure through deliberate misconduct. Further, where a Court would award punitive damages the penal idea behind such damages being awarded would be removed almost entirely by the company making indemnification. It is also doubtful whether a company could reimburse an executive for dishonest acts.

If these arguments are valid then it is also possible that they would equally apply to insurance purchased by the company to indemnify directors. This may have been the reasoning of the Ontario legislature when in the Business Corporation Act, 1970 it allowed a company to purchase insurance for its directors and officers but not such that it covered their failure to live up to the legislated standard of conduct.

\section{THE POLICY65}

The policy itself is in two parts-one indemnifying the company, and the other the directors-and is sold in one indivisible package. The corporate reimbursement policy covers sums spent by the corporation in lawfully indemnifying its executives while the directors and officers reimbursement policy covers unindemnified losses which the directors incur. It is necessary to have two policies because there may be some claims against directors for which the company cannot indemnify a director. ${ }^{66}$ In such a case, a policy carried by the com-

\footnotetext{
82 Re Brazilian Rubber Plantation and Estates, Ltd. [1911] 1 Ch. 425, and Re City Equitable Fire Insurance Company [1925] Ch. 407.

as e.g. Saskatchewan, R.S. S. 1965, c. 131, s 114, and British Columbia, R.S.B.C. 1960, c. 67, s 112.

o4 For detailed discussions of these arguments see Bishop, Sitting Ducks and Decoy Ducks: New Trends in the Indemnification of Corporate Directors and Officers, (1968) 77 Yale L.J. 1078; Public Policy and Directors' Liability Insurance (1967) 67 Colum. L. Rev. 716; and Liability Insurance for Corporate Executives, (1967) 80 Harv. L. Rev. 648.

os The following remarks are made on the basis of the Lloyds of London form of policy which has been the model for other companies entering this field.

os e.g. Possibly for those involving dishonesty or where the conduct was intentional.
} 
pany could not protect the director, although the director himself can carry a policy which does cover it. By use of the two policy system issued by one insurer there are also eliminated disputes which might otherwise arise between the company's insurer and the director's insurer as to whether a claim is of the type which the company could properly indemnify the director against.

\section{DIRECTORS' AND OFFICERS' LIABILITY POLICY}

\section{A. Insuring Clause}

The policy undertakes to pay on behalf of each and every person who was, is, or later becomes a director, loss arising from claims made against the insureds during the policy period by reason of wrongful acts in their capacity as directors or officers. Included in the definition of the word "director and officer" are present directors and officers of the corporation as well as those appointed in the future provided that notice of new appointments is given. A director of a parent company is also insured in his capacity as a director of that company's subsidiaries. Loss includes any amounts the insured is obligated to pay in respect of his legal liability, whether actual or asserted, for a wrongful act (as defined in the policy), and subject to other conditions of the policy, includes damages, judgments, settlements, costs, charges and expenses incurred in defence of actions, suits or proceedings-but does not include fines or penalties imposed by law or other matters deemed uninsurable under the law pursuant to which the policy is construed. It should be noted that the insurer has by the inclusion of these last words retained the right to deny payment on the basis of public policy.

A wrongful act is defined as meaning a breach of duty, neglect, error, misstatement, misleading statement, omission, or other act done or wrongfully attempted by the insured or any matter claimed against him solely by reason of his being a director and officer of the company in question.

The policy covers claims made against the estates, heirs and legal representatives of people who were directors or officers of the company at the time the acts upon which such claims were based were committed and also covers their legal representatives or assigns in the event of incompetency, insolvency or bankruptcy.

Excluded from coverage are the following claims:

(a) those made against the insured for libel or slander;

(b) based upon the director gaining in fact personal profit or -advantage to which he was not legally entitled;

(c) for return by the insureds of remuneration paid to them without previous approval of the stockholders of the company, which payment without such previous approval shall be held by the courts to have been illegal;

(d) for an accounting of profits in fact made from the purchase or sale by the assureds of securities of the company within the meaning of Section 16 (b) of The Securities Exchange Act of 1934 and amendments thereto or similar provisions of any state, statutory law or common law in the United States of America; 67

67 This section provides that for the purpose of preventing unfair use of information obtained by a director or officer by reason of his relationship to the issuer, the director is accountable for any profit made as 8 
(e) for liability to account to the company for any direct benefit or advantage received or receivable by the insured as a result of misusing confidential information which, if generally known, would affect the value of such securities in transactions relating to the capital securities of the company; 68

(f) based upon or attributable to any failure or omission on the part of the insureds to effect and maintain insurance;

(g) which, at the time of happening of such loss, is insured by any other existing valid policy or policies under which payments of the loss is actually made, except in respect to any excess beyond the amount or amounts of payments under such policy or policies;

(h) for which the insureds are entitled to indemnity under any policy or policies in force previously;

(i) for which the insureds shall be indemnified by the company for damages, et cetera, incurred in connection with the defence of any action, suit or proceeding and appeal therefrom;

(j) brought about or contributed to by the dishonesty of the insured. However, the insured is nonetheless protected against any claims upon which suit may be brought against him by reason of alleged dishonesty, unless the judgment or final adjudication thereof adverse to the insured shall establish that acts of negative and deliberate dishonesty committed by the insureds with actual dishonest purpose and intent were material to the cause of action so adjudicated.

A wrongful act of one director or officer is not imputed to other directors or officers for the purposes of determining the applicability of these exclusions. These exclusions destroy many possible arguments against such insurance based on public policy.

\section{B. Limits and Retention}

The insurer is liable for $95 \%$ of each loss over a $\$ 20,000.00$ deductible. In other words, the insured pays the $\$ 20,000.00$ deductible plus $5 \%$ of the judgment levied against him for each loss. In calculating the deductible costs, charges and expenses of litigation and negotiation are to be included. There is a prohibition against the insured insuring the $\$ 20,000.00$ deductible. Losses arising out of the same act or interrelated acts of one or more of the assureds are considered a single loss and only one retention of $\$ 20,000.00$ is retained. The purpose of this deductible is to prevent abnormally high premiums by eliminating the insurers responsibility for the more frequent smaller claims. It has a deterrent effect on carelessness or misconduct and also serves to make the insured combat weak and unfounded elaims rather than to merely rely on insurance to cover them.

\section{Costs, Charges, Expenses and Consent}

The policy provides that no costs, charges or expenses are to be incurred without the underwriter's consent which consent is not to

result of a purchase and sale, or any sale and purchase of securities of the issuer within any period of less than 6 months. This accountability is regardless of intention.

This is a paraphrase of s. 113 of the Ontario Securities Act, 1966, S. O. 1966, c. 142. The policy refers directly to this section or its equivalent legislation in other provinces-in Alberta the section is section 113 of the Securities Act, R.S.A. 1970, c. 333. 
be unreasonably withheld. If consent is given then the insurance company will, subject to the following three conditions, pay $95 \%$ of the costs, charges and expenses:

(i) If a payment not in excess of the limit of liability has to be made to dispose of a claim, costs, charges and expenses shall be payable in addition to the limits of liability, otherwise applicable...

(ii) If the claim is successfully resisted by the assureds, costs, charges and expenses shall be payable up to but not beyond the limit of liability under the policy.

(iii) If a payment has to be made to dispose of a claim in excess of the liability under the policy, the underwriter's liability to pay costs, charges and expenses shall be limited to such portions of the costs et cetera as the limits of liability bears to the amount paid to dispose of the claim, but underwriters' liability to pay costs, charges and expenses is in addition to the limits of the policy otherwise applicable...

These clauses are confusing and their meaning can best be understood by referring to a hypothetical situation. Assume a $\$ 20,000.00$ retention with a $\$ 500,000.00$ policy limit and

(a) a payment of $\$ 480,000.00$ to dispose of a claim plus costs, charges and expenses of $\$ 90,000.00$. The insurance company would pay $95 \%$ of $\$ 460,000.00(=\$ 437,000.00)$ plus $95 \%$ of $\$ 90,000.00(=\$ 85,500.00)$, namely a total of $\$ 522,500.00$. The directors insured would pay the deductible of $\$ 20,000.00$ plus $5 \%$ of $\$ 460,000.00(=\$ 23,000.00)$ plus $5 \%$ of $\$ 90,000.00(=\$ 4,500.00)$, namely a total of $\$ 47,500.00$.

(b) if the insured successfully resists the claim but incurs costs, charges and expenses of $\$ 90,000.00$ the insurance company would pay $95 \%$ of $\$ 70,000.00$ which is $\$ 66,500.00$. The directors insured would pay $\$ 20,000.00+\$ 3,500.00=\$ 23,500.00$.

(c) if the amount paid to dispose of the claim was $\$ 650,000.00$ plus costs, charges and expenses of $\$ 80,000.00$. The insurance company would pay its $\$ 500,000.00$ policy limit plus $10 / 13$ of $\$ 80,000.00$ which gives a total of $\$ 561,530.77$. Those insured would pay $\$ 150,000.00$ plus $3 / 13$ of the $\$ 80,000.00$ which is a total of $\$ 168,469.23$.

The insureds are not required to contest any claim unless a mutually agreed upon counsel advises that it should be contested by the insured. The insurer has the right to take over defence or settlement in the insured's name.

It should be noted that under the policy the insured conducts his own defence which is quite unlike automobile and most other types of insurance. He is free to settle or litigate within the bounds of reasonableness. This is probably more appropriate in this type of policy than an automobile policy since a businessman is probably more sensitive to publicity and its impact upon his reputation and, therefore, would prefer to have more control over settlement himself than is necessary in an automobile policy.

\section{Loss Provisions}

Usually a "loss" occurs when the act in question is committed. However, the policy provides that a loss is deemed to have been incurred on the date on which the company or the insured gives written notice to the underwriters and the insured must give written notice as soon as possible of any claims. If notice of intention to bring action 
is served or the insureds become aware of an occurrence which may give rise to a claim and notify the company in writing prior to the expiration of the policy period then they are covered even though the claim is brought after the policy expires.

In the event the policy is cancelled or a renewal is refused the insureds have an option of paying a set percentage of the three year premium and thus obtaining coverage for claims made for the next twelve months if the wrongful act occurred before the date of cancellation. The premium is generally $8.33 \%$ of the three year premium.

The insurer reserves the right to cancel at any time the policy upon giving thirty days notice. Portions of the premiums are returned in the event of cancellation.

\section{COMPANY REIMBURSEMENT POLICY}

The corporate reimbursement policy clauses are much the same as the directors clauses and, therefore, they shall not be considered in detail.

The corporate policy in the insuring clause undertakes to pay on behalf of the company, loss arising from claims made by reason of wrongful acts of directors and officers, but only covers those losses for which the company is required or permitted to indemnify the directors and officers. Loss in this policy means amounts the company is required or permitted by law (statutory or common), or the bylaws of the company, to pay to a director as indemnity for claims arising out of the acts contemplated by the policy and includes damages, judgments, settlements and costs, charges and expenses incurred in the defence of actions or suits. It does not, of course, include fines, penalties or other matters deemed uninsurable under the law pursuant to which the policy will be construed.

The insurer is not liable to make any payment for loss in connection with any claim made against the directors or officers which at the time of loss was insured by an existing and valid policy under which payment of the loss is actually made except the excess beyond the amount payable under such other policy. Further, the insurer will not make payments in respect of claims made against the directors or officers for which they are entitled to indemnity under any policy previously in force. These are the only exclusions in the company policy.

\section{PREMIUM PAYMENT}

A matter of concern, especially to the directors, is how the premiums are paid. One alternative is for the company to pay the entire premium covering both policies. The problem with using this method is that there may be public policy arguments against the company purchasing insurance which will cover directors with respect to sums for which the company could not lawfully indemnify the director. What these particular items are and their magnitude depends upon the articles of association of the company, the common law, and the statute law of the particular jurisdiction. Under the Ontario Business Corporations Act, $1970^{69}$ the company cannot insure the director for failing to live up to the legislated standard of care, and therefore, the company could not pay the entire premium. If this method of premium 
payment is used, however, it should be noted that the director could be taxed on the benefit he receives. ${ }^{70}$ Inasmuch as the insurance company charges one premium covering both policies it is impossible for both the director and the company to pay the premiums on their respective policies. The usual method is for an arbitrary premium split to be made. From a review of the authorities available, ${ }^{71}$ the normal method would appear to have the company pay $90 \%$ of the premium and the directors $10 \%$ of the total premium. In jurisdictions in which there are no statutory restrictions on indemnification this would superficially seem to be fair as most losses a director incurs would be indemnifiable by the company and thus, payments would be made to the company under the company policy. However, in Ontario under the Business Corporations Act, $1970^{72}$ a company cannot insure a director for failing to live up to the legislated standard of care and thus, it is necessary to make a much more careful decision in arriving at what is a fair premium spilit. If a premium split is made the company could, if it wishes, reimburse a director for his portion of the premiums by means of an increase in his director's fees. In view of the tax rates if full restitution is to be made a raise larger than the premium would have to be made as the additional income would also be taxable in his hands.

Some provinces have provisions which read substantially as follows: ${ }^{73}$

A provision whether contained in the articles of a company or in a contract with a company or otherwise, for exempting a director, manager or other officer of the company, from, or indemnifying him against, liability that by virtue of any rule of law would otherwise attach to him in respect of negligence, default, breach of duty or breach of trust of which he may be guilty in relation to the company, is void.

Such a provision does not prevent the company from indemnifying a director who is not guilty or is declared innocent of the named matters, but it is arguable that the section has the effect of prohibiting the company from providing negligence insurance for its directors as this insurance covers them regardless of guilt or innocence. However, it is submitted that what the section is aimed at regulating is indemnification agreements between a company and its directors and should not and does not prevent agreements being made with others by either directors or the company for indemnification for acts for which the company is prohibited from directly indemnifying the director. If a contract of insurance is entered into it is the insurer and not the company who indemnifies the director.

\section{EVALUATION OF POLICY}

One of the major questions which a company, and therefore its counsel, must consider in deciding whether or not to purchase the insurance is whether it is worth the apparent relatively high cost. ${ }^{74}$ It is

30 Section 5 (1) (a) of Income Tax Act, R.S.C. 1952, c. 148, and see Plumb v. M.N.R. [1970] Tax A.B.C. 139.

"Bishop, supra, n. 64, and a memorandom entitled Directors' and Officers' Liability Insurance: Some Management Considerations published by the Machinery and Allied Products Institute in 1969.

72 S. O. 1970, c. 25, s. 147(3) (Interim Edition).

${ }^{73}$ e.g. Saskatchewan-R.S.S. 1965, c. 131, s. 114, and British Columbia-R.S.B.C. 1960, c. 67, 8. 112.

21 It is the writer's understanding that in 1969 for the smallest risks acceptable a premuim of at least $\$ 10,000$ is required for the first $\$ 1,000,000$ and at least $\$ 2.50$ per $\$ 1,000$ for further millions. These are three year premiums and increase as the risk insured increases. They have also undoubtedly increased due to the recent statutory changes to the company law of Ontario. 
difficult to evaluate a policy such as this without having regard to specific fact situations. The problem of evaluation is made all the more difficult by reason of the fact that the policy is not particularly well drafted and it is difficult to interpret certain provisions. Apparently, improvements have been made in the drafting in the last year or two but in the words of one authority: 75

... in three short years the draftmanship of the Lloyd's Standard Form (and its American imitators) has progressed from the grotesque to the merely inept, and there is no reason to suppose that the underwriters counsel have come to the end of their ability to learn.

Some of the more difficult ambiguities to sort out are found in the exclusionary provisions of the policy. For example, in exclusion (b) referred to earlier it may be difficult to determine which profits or advantages a director is legally entitled to and those which he is not. There also may be a problem in deciding whether there is a difference between dishonesty in exclusion (j) and not being legally entitled to a profit or advantage in exclusion (b). Exclusion (c) referred to previously is difficult to understand in view of the fact that it is not uncommon to have in the articles of association a provision that the directors shall determine what their remuneration shall be. If the directors set their remuneration on the basis of the authority of such an article it is difficult to conceive of a court labelling this as being illegal, which is the word which appears in the policy.

It may be useful to briefly review some of the potential liabilities of a director against the exclusionary provisions of the policy in order to determine whether such liabilities are covered.

Many breaches of a director's fiduciary duty to the company would not be covered by the policy due to the exclusionary provision which provides that the underwriter is not responsible to make payments in connection with claims based upon or attributable to the director gaining any personal profit or advantage to which he was not legally entitled. These breaches may also be excluded from coverage as being contrary to public policy and thus not within the definition of the word "loss". Therefore, a director who makes secret profits or appropriates corporate advantage to himself would not be covered by the policy.

Apart from elements of dishonesty or gaining a profit or advantage to which a director is not legally entitled a director's potential liability to the company for application of its assets in ultra vires transactions and for negligence would appear to come within the ambit of the policy. However, in view of the infrequency of such actions in Canada it would be hard to justify a large expense to cover such risks.

The fines or penalties imposed by the amendments to the Canada Corporations Act and fines imposed under other Acts are not covered because they are excluded from the definition of the term "loss" in the policy. Most of these fines would be at any rate under the $\$ 20,000.00$ deductible of the policy. A director may be reimbursed for these fines by the Company if statute law, the articles of association and public policy allow it.

The greatest potential liability of a director is for deceit in relation to a prospectus and for the liability imposed under the Securi-

75 Bishop, supra, n. 64 at 1090. 
ties Act ${ }^{76}$ and the Companies Act ${ }^{77}$ for misrepresentations in a prospectus. Apart from elements of dishonesty or improper advantage such losses would seem to be covered. This coverage, in the writer's opinion, would be the main argument in favour of such insurance.

Liability imposed under Section 98d of the Canada Corporations Act ${ }^{78}$ for misuse of confidential information would not be covered due to the element of personal gain. Similarly, liability imposed under the Securities Act ${ }^{79}$ and the Companies Act ${ }^{80}$ for breach of the insider provisions relating to use of confidential information are specifically excluded from coverage.

The statutory liabilities for wages, loans, and payments of dividends would usually, depending upon the particular circumstances, be covered.

On the basis of present Alberta law it is difficult to decide whether this insurance is worth its relatively high cost. This type of insurance would appear at present to be of greatest value to a public company who finances regularly, but in view of the trend towards higher standard, of care being demanded of directors the value of such insurance would seem to be on the rise. If the trend is to continue there may well come a time in the not too distant future when candidates for directorships make it a condition of accepting that such coverage be made available.

\footnotetext{
76 R.S.A. 1970, c. 333, 8. 141

7 R.S.A. 1970, c. 60, s. 96.

7s.C. $1969-70$, c. 70.

79 R.S.A. 1970, c. 333, s. 113.

$\infty$ R.S.A. 1970, c. 60, s. 88e
} 